\title{
Economic Valuation of Mangrove Forest at Taman Ayu Village, West Lombok Regency
}

\author{
Siti Dian Rosadi ${ }^{1,}$, , Mufti Petala Patria $^{2}$, and Nisyawati ${ }^{3}$ \\ ${ }^{1}$ Department of Biology, FMIPA Universitas Indonesia, Kampus UI Depok, Depok 16424, Indonesia, \\ Tel. +62-857-7300-6171
}

\begin{abstract}
Research regarding economicvaluation of mangrove forest in Taman Ayu Village, West Lombok Regency has been conducted. The purposes of this research were to calculate and analyze economic value of benefit from mangrove foresteco system. Collecting data was conducted through observations and interviews. Results of direct benefit economic value wereobtained fromdirect exploitation by local comunity. Direct value benefit of mangrove forest were Rp. 227.040.000/year. Indirect value benefit obtained frome cosystem service of mangrove forest with a value Rp.1.405.041.200/year. Existence value benefit was obtained by using method of CVM (Contingent Valuation Method)with a value Rp. 1.520 .000 /year. Option value benefit was obtained from biodiversity value with a valuewere Rp.1.200.000/year. Total Economic Value (TEV) of forest mangrove in Taman Ayu Village were Rp. 1.634.801.200/year.
\end{abstract}

\section{Introduction}

Mangrove ecosystems in Indonesia continue to sufferfrom damage [1,2]. Mangrove damage in Indonesia, one of which occurs on the island of Lombok [3, 4]. Based on data from the Badan Pengendalian Daerah Aliran Sungai (BPDAS)[5], as much as 50.3\% of mangrove ecosystems on Lombok Island weredamaged. The damage was caused by land conversion [4], tourism[3], illegal logging and exploitation of building materials and fuel wood[5,6].

In addition, the high level of mangrove damage on the island of Lombok is also caused by the low appreciation of the community towards mangroves. Mangroves are considered as valuable land that does not provide any economic benefits. Therefore, people prefer to do land conversion, logging and exploitation because they are considered to provide tangible economic benefits [7].

The community does not realize that the presence of mangroves can provide a large economic value compared to its destruction [8]. These economic values can be obtained from the value of direct benefits, indirect benefits, option values and existence values [911]. The economic value of the direct benefits of mangroves is derived from fisheries, medicines, animal feed, salt, tourism, education and so on. The economic value of

*Corresponding author: sitidian21@gmail.com 
mangrove indirect benefits can be obtained from ecosystem services $[9,12]$ and the physical function of mangroves as a deterrent to abrasion and waves [7, 9,12]. The option values of mangroves can also provide economic benefits such as genetic resources [13]. Existence values can provide economic benefits in the form of the value of mangrove existence for the future $[10,14]$. All of these values can be revealed and known through economic valuations.

One of the mangrove areas on Lombok Island that has not been valuated is in Taman Ayu Village. Mangrove areas in the area are vulnerable to damage. Damage caused by mining activities and illegal logging [6,11]. Therefore the research was carried out in the area, because the results of the research obtained were expected to provide information and understanding to the community regarding the importance of mangroves, so that the community do not destruct it anymore. The purposes of this research are to calculate and analyze the economic value of benefits from mangrove forest ecosystem.

\section{Materials and Methodes}

The study was conducted from February until August 2018. The data were collected in Taman Ayu Village, Gerung Sub-district, West Lombok Regency (Figure 1.). Collecting data was conducted through observation and interviews. The interview informants were determined by purposive sampling method $[7,10,14]$. The informants were 30 people or $10 \%$ of the total population in the village. Data collectedincludes mangrove values from direct use, indirect use, options values and existence values.

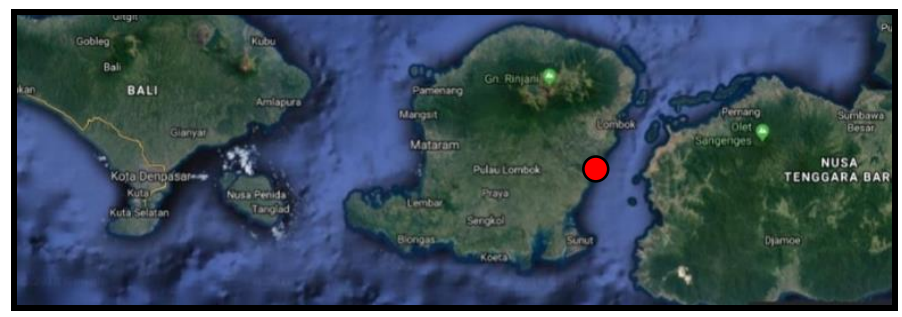

Fig. 1. Map of location of data retrieval

\section{Results and Discussions}

Taman Ayu Village community is a community that lives around the mangrove area of Taman Ayu Village. The number of people living in Taman Ayu Village reaches 300 people and $90 \%$ of them are migrants. Communities generally make a living as breeders and farmers. This can beseen from the number of farms and agricultural land adjacent to the mangrove area. The people who live in Taman Ayu Village still live intraditional way. This can beseen from the shape of the building and their daily habits.

Based on observations it can beseen that Taman Ayu Village has a fairly large mangrove area of around 8 ha. The mangrove area is spread fromcoastal waters up to several hund red meters to the upper reaches of the Taman Ayu river. The exploitation of mangroves is carried out by the community such astowards the resources of sand, wood and fishery products. The biggest exploitation is carried out onsand and wood resources. This can beseen from many activities of timber harvesting and utilization and the number of sand mining activities in the mangrove area.

The exploitation is part of direct use whose economic value can bee valuated. In addition to the economic value of direct benefits, the economic value of other benefit salso 
needs to be evaluated. This is donein order to get information and to increase public a wareness that mangroves have other economic values that are important in addition to the economic value of current direct exploitation by the community. The followingis the overall economic value of the mangrove in Taman Ayu Village which has been evaluated:

\subsection{Direct Use Value}

The value of directbenefitsis the economic value obtainedfrom the direct use of natural resources and the environment (Barbier et al. 1994). The value of direct mangrove benefits in Taman Ayu Village that has been evaluated can beseen in (Table 1).

Table 1. Direct use value

\begin{tabular}{|c|c|c|}
\hline No. & Resources & Amount (Rp/year) \\
\hline 1. & Shrimps & 1.530 .000 \\
\hline 2. & Shells & 1.664 .000 \\
\hline 3. & fuelwood & 9.860 .000 \\
\hline 4. & Fish & 216.000 \\
\hline 5 & Crabs & 60.000 \\
\hline 6. & Sand & 189.000 .000 \\
\hline 7. & Coconut & 6.900 .000 \\
\hline 8. & Cocnut leaf & 45.000 \\
\hline 9. & Grass & 12.125 .000 \\
\hline 10. & Bamboo & 1.680 .000 \\
\hline 11. & Buah-buahan & 3.960 .000 \\
\hline \multicolumn{2}{|c|}{ Total } & 227.040 .000 \\
\hline
\end{tabular}

The highest economic value of mangroves in Taman Ayu Village was obtained from the use of sand, which was Rp. 189.000.000/year. This value is obtained from the multiplication of the sand market price of Rp. 75.000/dam multiplied by the amount of utilization which reached 2.520 dams each year. Based on observations, it can be seen that the high utilization of sand in mangrove areas Taman Ayu Village is caused by the high availability of resources in the form of estuary sand deposits. Satellite observations indicate that the estuary in Taman Ayu Village is a large estuary resulting from the confluence of various large rivers in West Lombok Regency such as the river from Lembar Subdistrict and also Gerung District. This is assumed to be the reason for the high availability of sand resources in Taman Ayu Village.

Other uses, such as fuelwood, are also commonly done by the community. The economic value generated from the use of fuel wood reaches Rp. 9.860.000/year. This value is obtained from the multiplication of the firewood price in the amount of $\mathrm{Rp}$. 10.000 /bundle multiplied by the amount of utilization that reaches 986 bundles per year. The high use of fuelwood is caused by people who still traditionally use fire stoves as a substitute for stoves.

The lowest economic value is obtained from the utilization of young coconut leaves. This iscaused by the frequency of the time of use of young coconut leaves which isvery rare, that is only on major holidays of Islamic celebrations. Besides that, the use of coconut leafs is also not commonly used compared to the use of other resources that play a role in ful filling food and board needs.

\subsection{Indirect Use Value}


Value of indirect benefits is the economic value obtained from indirect use of natural resources and the environment $[9,10,13]$. The indirect benefits of mangroves in Taman Ayu village which were evaluated include retaining abrasion andwaves (Table 2.). Economic value isquantified by the replacement costmethod by estimating the economic value of making break water $[10,13,15]$.

The price data for the construction of break water were obtained using standard prices from the Kementerian Pekerjaan Umum(PU). The cost of making a dike with a size of $50 \mathrm{~m}$ x $1.5 \mathrm{~m} \times 2.5 \mathrm{~m}(\mathrm{p} \times 1 \times \mathrm{t})$ with a 5year durability ofRp. 291.994 .000 or Rp. 5.839.880/meter. The length of the coastline in Taman Ayu Village is 1200 meters, so that the economic value of Rp. 7.007.856.000/meter or Rp. 1.401.571.200/year.

Other indirect benefitsthat are evaluated are as nursery ground, spawning ground and feeding ground. The value is quantified from the catch of fish ery products such as shrimp, shell fish and fish obtained by the community from mangrove areas $[13,15,16]$. The results of the data calculation show that the economic value obtained reachesRp. 3.470.00/year.

Table 2. Indirect Use Value)

\begin{tabular}{|c|c|c|}
\hline No. & Estimated resources & Amount (Rp/year) \\
\hline 1. & Breakwater & 1.01 .571 .200 \\
\hline 2. & Nursery ground, spawning ground dan feeding ground. & 3.470 .000 \\
\hline \multicolumn{2}{|c|}{ Total } & 1.405 .041 .200 \\
\hline
\end{tabular}

\subsection{Option Value}

This value represents the potential economic value obtained from the use of resources in the future. One of the examples is the choice of rice diversity for future geneticimprovement of rice [13]. The values are generally quantified using the benefit transfer method, which is by calculating the value of biodiversity in the mangrove ecosystem. Mangrove forests in Indonesia have a biodiversity value of US $\$ 1.500 / \mathrm{km}^{2}$ or US\$15/ha [17]. Based on this calculation, the economic value of the option benefits mangove Taman Ayu Village in 2018, reaching US\$120/ha or Rp. 1.200.000/ha. This value is the result of the multiplication of biodiversity values with an area of existing mangrove forests of $800 \mathrm{~m}^{2}$ or 8 ha.

\subsection{Existence Value}

Quantification of the existence benefits is done by directly measuring individual preferences through the Contingent Valuation Method (CVM). The method is done through interviews by asking how much the Willingness To Pay (WTP) from the community in maintaining the existence of mangroves [16]. Economic value is obtained by multiplying the average value $(\mathrm{Rp})$ given by the informant to the presence of mangroves per ha per year with the total area of mangrove forests [9]. Based on the assessment approach using CVM on 30 informants, it can be seen that the value of the benefits of the existence of mangrove forest in Taman Ayu Village is Rp.190.000/ha/year or Rp. 1.520.000/year.

\subsection{Total Economic Value (TEV)}

Total Economic Value (TEV) is the overall economic value of the sum of direct benefits, indirect benefits, optionvalues benefits, and existence values benefits[7,9,10,12,15]. The mangrove TEV in Taman Ayu Village in 2018 reached Rp. 1.634.801.200 / year (Table 3.). 
Table 3.Total Economic Value (TEV)

\begin{tabular}{|c|c|c|}
\hline No. & Benefit & Amount (Rp/year) \\
\hline 1. & Direct Use Value & 227.040 .000 \\
\hline 2. & Indirect Use Value & 1.405 .041 .200 \\
\hline 3. & Option Value & 1.200 .000 \\
\hline 4. & Existence Value & 1.520 .000 \\
\hline \multicolumn{2}{|c|}{ TEV } & 1.634 .801 .200 \\
\hline
\end{tabular}

When compared to the TEV of mangrove forests in other regions, especially Lombok, this value is relatively smaller. For example, when compared to East Lombok mangrove TEV which reached Rp. 50.295.895.476/year [9]. The mangrove TEV value in Taman Ayu Village is also much lower when compared to the mangrove area outside Lombok Island, including when compared to the TEV of the Coastal District of Merauke Regency which reaches Rp. 213.344.656.759/year [13]. In addition there are also mangrove TEV in Dompak Island, Riau Islands which reached Rp. 88.257.253.176/year [10]. Or the Mahakam delta mangrove forest of Rp. 503.071.398.869/year [12].

Based on Table 3. When compared between all existing values, the largest economic value is more obtained from thein direct values benefits. This indicates that ecosystem services play an important role in providingeconomicbenefits. The otherhighesteconomic value is obtained from the direct benefit value. This iscaused by people who still consider that mangrove forests need to beexploited to the maximum extent possible to improve their welfare. While the low value of indirect benefits, the value of choice and the value of existence is due to the lack of public awareness of the importance of the economic value of natural resources andenvironment.

\section{Conclusion}

Results of direct value for forest mangrove benefits were Rp. 227.040.000/year. Indirect value benefit were Rp 1.405.041.200/year. Benefit existence were Rp. 1.520.000/year. Option benefits reach 1.200.000/year. Total economic value benefit of Taman Ayu Village mangrove was Rp. 1.634.801.200/year. When compared to the TEV of mangrove forests in other regionsthis value is relatively smaller.

\section{Acknowledgments}

Thank you to village Head and all staff involved. Do not forget to all the interviewees who have been active in the data collection activities.

\section{References}

1. Kuswata, K., S. Soemodiharjo and S. Prawiriatmojo. J. OseonologiIndonesia 7 (1977)

2. KementerianKehutanan, Statistik Kehutanan Indonesia 2011 (Direktorat Jenderal Planologi, Kehutanan, Jakarta, 2012)

3. Wong, P.P. J. Ocean and Coastal Manajement 38 (1998)

4. Subhan, M., M. Antara and I.A. Astarini. J. Ecotrophic 8 (2014) 
5. Badan Pengendalian Daerah Aliran Sungai (BPDAS) Dodokan Moyosari, Kondisi dan status mangrove di wilayah kerja BPDAS Dodokan Moyosari (Departemen Kehutanan Propinsi NusaTenggara Barat, Lombok, 2007)

6. Bonita, M.K. and W.Y. Nizar. J. Media Bina Ilmiah 8 (2014)

7. Johari, H.I. J. Media Bina Ilmiah 3 (2007)

8. Junaidi. J. Jurnal Penelitian Universitas Mataram 8 (2014)

9. Suzana, B.O., J. Timban, R. Kaunang and F. Ahmad. J. Akademik Sains Economic 7 (2011)

10. Zen, L.W. and F. Ulfah. J. Dinamika Maritim 4 (2013)

11. Wahyuni, Y., E.I.K. Putri and S.M.H. Simanjuntak. J. Penelitian Kehutanan Wallacea 3 (2014)

12. Widiastuti, M.M.D., N.N. Ruata and T. Arifin. J. SosialEkonomi 11(2016)

13. Barbier, E.B. Valuing Environmental Functions: Tropical Wetlands (University of Wisconsin Press, Wisconsin, 1994)

14. Hiariye, L.S. J. Organisasi dan Manajement 5 (2009)

15. Arifitria, R.I., R. Qurniati and S. Hernawati. J. Jurnal sylva Lesatri 2 (2014)

16. Noor, P. and Helminuddin. J. KehutananTropika 2 (2009)

17. Ruitenbeek, H.J. Mangrove management: An economic analysis of management option witha focus on Bituni Bay, Irian Jaya (Environmental Management Development in Indonesia Project, Jakarta, 1991) 